Kalamatika: Jurnal Pendidikan Matematika

\title{
THE ANALYSIS OF MATHEMATICAL LITERACY ON PLANE GEOMETRY MATERIAL WITH BATIK BETA WI TUMPAL PATTERN
}

\author{
Vyvy Hindun Permatasari' ${ }^{1}$, Meyta Dwi Kurniasih ${ }^{2}$ \\ ${ }^{1}$ Universitas Muhammadiyah Prof. DR. HAMKA, Jl. Tanah Merdeka, Jakarta Timur, Indonesia. \\ vyvypermata@gmail.com \\ ${ }^{2}$ Universitas Muhammadiyah Prof. DR. Hamka, Jl. Tanah Merdeka, Jakarta Timur, Indonesia. \\ Meyta.dkurniasih@uhamka.ac.id
}

\section{ABSTRACT}

Batik Betawi is one of the elements of Betawi culture heritage that needs to be reserved. This element of Betawi culture can be used as a learning and teaching media since it has patterns correlated to mathematics. One of the patterns that can be used as a mathematics lesson at school is the batik Betawi tumpal pattern, formed by triangles and squares. This research aims to examine the role of Betawi culture in mathematical literacy. This research implements the qualitative descriptive method with ethnographic approach. The results show that batik Betawi tumpal has a significant effect on mathematical literacy and it is also applicable to the teaching of plane geometry. Batik Betawi tumpalpattern as one of the elements of Betawi culture is relevant to use as a teaching media of plane geometry. It can also be used a s tool to visualize the object in concrete form to be more comprehensible for the students.

ARTICLE INFORMATION

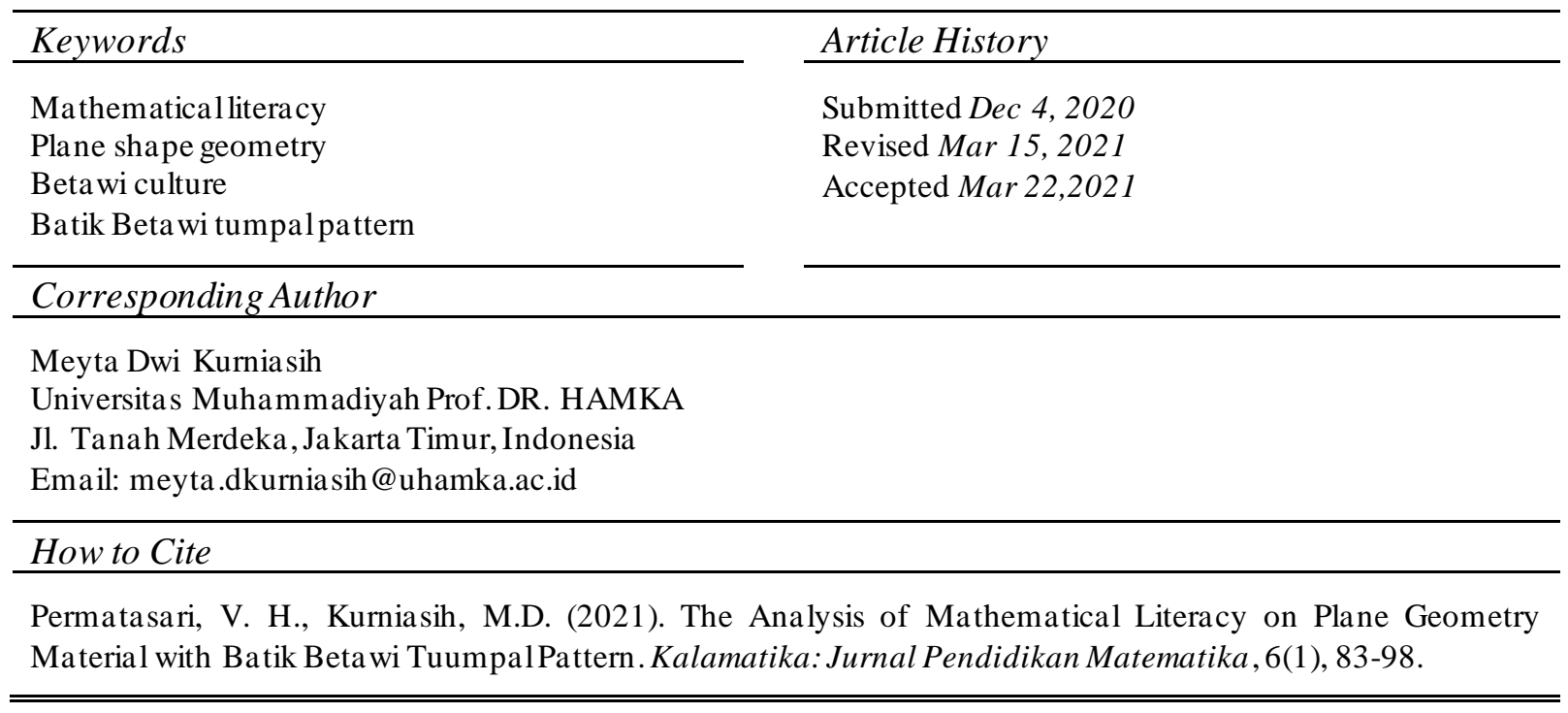

https://doi.org/10.22236/KALAMATIKA.vol6no1.2021pp83-98

\section{$(\mathrm{cc})$ BY-SA}

This work is licensed under a Creative Commons Attribution - ShareAlike 4.0 International 


\section{INTRODUCTION}

The emergence of industrial revolution 4.0 is marked by the vast development in the internet and telecommunication sector. Students have to adopt knowledge and implement what they have learn to make them more critical in accepting and in processing information. The 2013 curriculum goal is to give the students a higher mathematical literacy which is depicted in the competency in standard content of the curriculum. This curriculum can create a problem for the students, especially in mathematics. Students need mathematical literacy to solve problems. Among the kinds of literacy are reading and writing literacy, science literacy, financial literacy, digital literacy, cultural literacy and citizenship literacy.

The word literacy in English is originated from Latin 'littera' (letter), which means the ability of the writing system (Afriyanti et al., 2018). Mathematical literacy is meant for all ages, and also identical to someone's knowledge and their capability. PISA explained that someone's capability consists of several levels and simulations. This level is used to represent a country which has a low and high mathematical literacy (Stacey, 2015). In brief, literacy is a human's awareness to think creatively and critically through the activity of reading and writing (Maryati \& Priatna, 2018). PISA 2012 results, released in December 2013 showed that the position Indonesian mathematics performance is 64 among 65 countries (Yenni, 2016). While in 2015 Indonesian only sat at 69th place from 76 countries (Fathani, 2016). Thus, mathematical literacy is a person's ability to think critically and creatively in formulating, describing as well as explaining in line with the mathematical concept in his daily life, through activity of writing and reading. The ultimate benefit of mathematical literacy is to have those abilities above. The real example of mathematical literacy is in the working community. Even in the full digital era with a high technology system, the skill in mathematical literacy is still relevant for the employees from middle to higher level of managerial. Every employee needs to comprehend a system and how to improve. Another example is when shopping, there are many products offered with a discounted price or voucher reward. Someone with a high mathematics literacy will never get confused in choosing which goods are more effective (Hera s\& Sari, 2015). Another concrete example of mathematical literacy is when someone has to choose between alternative line A and B. The ability of mathematical literacy divided into several indicator levels, as shown in Table 1 (Khotimah, 2018). 
Tabel 1. The Indicators of Mathematical Literacy Competency

\begin{tabular}{ll}
\hline \multicolumn{1}{c}{ MathematicalLitera cy Aspect } & \multicolumn{1}{c}{ Indicator of Achievement } \\
\hline $\begin{array}{l}\text { Formulating problems mathematically } \\
\text { Using fact, concepts, procedure and mathematical } \\
\text { reasoning }\end{array}$ & $\begin{array}{l}\text { Identify problems into mathematical form } \\
\text { Doing reasoning based on given facts } \\
\text { Determining the procedure which will be applied based on given } \\
\text { assumption }\end{array}$ \\
$\begin{array}{l}\text { Selecting and applying a simple problem-solving strategy b a sed on } \\
\text { facts or different resources } \\
\text { a mathematical process }\end{array}$ & $\begin{array}{l}\text { Communicating the explanation by giving arguments based on } \\
\text { interpretation of the suggested problem }\end{array}$
\end{tabular}

Source: (Khotimah, 2018)

Education comes from a culture that develops in an educational scope which results in the change in the social sector (Alghadari, 2017). Therefore, from an educational context, it can be said that mathematics is a reflection of a culture that has some obvious elements, like language, habits, lifestyle, livelihood, knowledge and others. A knowledge about one culture can be seen from the educational system adopted by the community living in that area. So, mathematics is born from culture, the more developed culture, the more developed mathematics and the educational system of the community. Culture, or budaya in bahasa originated from Sanskrit language Budhayah, a plural form of budhi meaning mind (Setiadi et al, 2017).

Furthermore, culture is a whole complex including knowledge, faith, art, law, moral, traditional custom and every existing ability and habit adopted by humans as a society (Supriadi et al., 2016). So, culture is a knowledge system covering the system of idea in the form of thought, moral, human work, law, and art. It is used by a group of a certain community in their daily lives. Many kinds of Indonesian culture heritage lost and forgotten. Those heritage needs to be maintained by incorporating the cultural knowledge into literacy at school. One of the forgotten heritages is Betawi culture, including its culinary art, music, dance, clothes, craft and traditional celebration. Batik Betawi tumpal can be used as a learning medium for mathematics in school.

Batik Betawi tumpal is considered a sacred mountain or "meru" because the pattern symbolizes greatness and fertility (Soedarwanto et al., 2018). Tumpal pattern has geometrical shapes, such as triangles and squares. In the figure 1 shape of triangle is depicted as a line surrounding the head and the body part of the fabric. Triangle shapes in a tumpal pattern symbolize the crocodile teeth (Kusumowardhani, 2017) it makes the batik named batik Betawi tumpal pattern crocodile teeth. Therefore, batik Betawi tumpal can be used as a learning medium for plane geometry. 


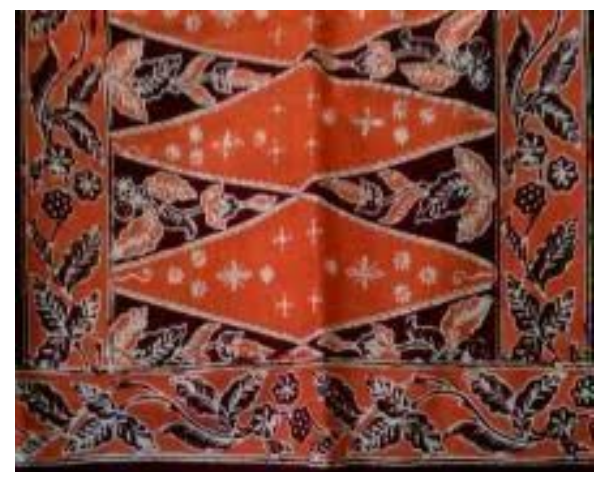

Figure 1. Batik Betawi Tumpal Pattern Crocodile Teeth (Kusumowardhani, 2017)

Since Indonesia was only in 69th place out of 76 country participants in Mathematical Literacy during PISA 2015, therefore, students need to develop their mathematical skills. Introducing Betawi culture to the students through mathematical learning at school, like using batik Betawi tumpal to teach plane geometry, help students to understand the lesson easily and preserve the cultural heritage. Introducing batik to the students can also emphasize the international recognition of Indonesian batik as an original Indonesian culture given in Paris in October 2009 by the United Nations Educational, Scientific and Cultural Organization (UNESCO) (Alghadari, 2017). Using culture or other objects in daily life as a medium of teaching or learning mathematics is called ethnomathematics. Researchers researched and developed mathematics and culture learnings in the 1980s, later known as ethnomathematics (Abi, 2017). Ethnomathematics was first introduced by D'Ambrisio in 1985 (Budaya et al., 2017), who stating that ethnomathematics is a view in understanding mathematics as a result of the culture's existence. In a mathematical literacy context ethnomathematics is a learning method referring to the culture's symbols applied to the mathematical concepts using the students' thinking skills.

\section{METHOD}

This research used the qualitative descriptive method. Qualitative method is a method based on post positivism philosophy (Sugiyono, 2016). In this research, the researcher was the key instrument, while technique of data collection was triangulation (combination). The data analysis was conducted qualitatively and the results of the research emphasizing the meaning rather than the generalization. The approach used in this research was an ethnographic approach focusing on batik Betawi tumpal and relating the subject with mathematics to form the ethnomathematics to figure out the mathematical literacy of learning the plane geometry. 
The ethnography approach is sourced from the lifestyle and daily activity of living things inherited from a community (Lusiana et al., 2019). The approach used in this research was the ethnograpic approach that correlates with procedural research (Rakhmawati, 2016)

The ethnographic approach consists of several activities. First, the researchers designated the informant, one of the prominent Betawi society's Ibu Lemah or we also call Nyak Lemah. Second, the researcher conducted interviews in Jaticempaka, Pondok Gede, Bekasi. Third, the researcher kept an ethnographic record of documenting the informant and the weakened conditions of the house Betawi Nyak Lemah. Fourth, the researcher posed a descriptive and narrative question about batik Betawi as the motif for learning mathematics. Fifth, after the research was completed, the researcher wrote an ethnography in the form of a narrative explanation of the results of the findings studied. The ethnographic approach was sourced from the Betawi batik with tumpal pattern, associated with mathematics plane geometry for the seventh-grade students. The research was conducted in Junior High School Muhammadiyah 4 Jakarta, East Jakarta City. The data were collected by interview, questionnaire, and the observation of the findings obtained during the research process. The researcher also took some documentation related to the observation, including the traditional house of Betawi, tool and equipment that are still in use to this day as well as the pictures of the students at the time they were doing the mathematical literacy problems during mathematics learning using batik Betawi tumpal. The questionnaires consisting of 25 questions were only given to five students. After collecting the data, the researcher combined the findings using the triangulation technique.

\section{RESULTS AND DISCUSSION}

Based on the research, two main findings as the result of observations, the interview, questionnaire feedback, and the documentation are described as follows. First, batik Betawi tumpal can influence the mathematical literacy in plane geometry. Batik Betawi tumpal is one of Betawi culture heritage that needs to be preserved. As in figure 2 batik Betawi with some plane geometry pattern containing triangles and squares is batik Betawi tumpal. The length of batik Betawi fabric sheet, in general, is $1.5 \mathrm{~m}$ and width $0.5 \mathrm{~m}$. 


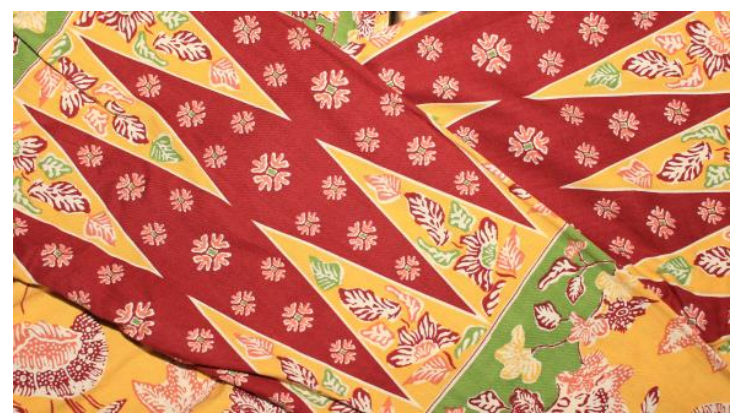

Source: https://belajarcerita.com/2017/12/12/batik-betawi-jakarta/

Figure 2. Batik Betawi Tumpal Pattern

Every pattern of batik Betawi has its own meaning and history. The mathematical literacy concepts in plane geometry learning are based on batik Betawi tumpal with triangles in its pattern. A triangle is a two-dimensional figure that has three lines and total angles of $180^{\circ}$. Triangle classified according to its side, angles and characteristic. According to its side there are isosceles, equilateral and right-angle triangles. According to its angles, there are right angles, acute and obtuse triangles. Based on its characteristic, there are right angle triangles with two equal sides, acute triangles with two equal sides, obtuse triangles with two equal sides. Quadrilaterals are a plane shape that has four lines and total angles of $360^{\circ}$. There are six types of quadrilateral: rectangles, squares, parallelogram, rhombus, kite and trapezium. In the aspect of learning in mathematical literacy, the students will observe the plane geometry, classified based on their characteristics and shapes and point to the plane geometry by name.

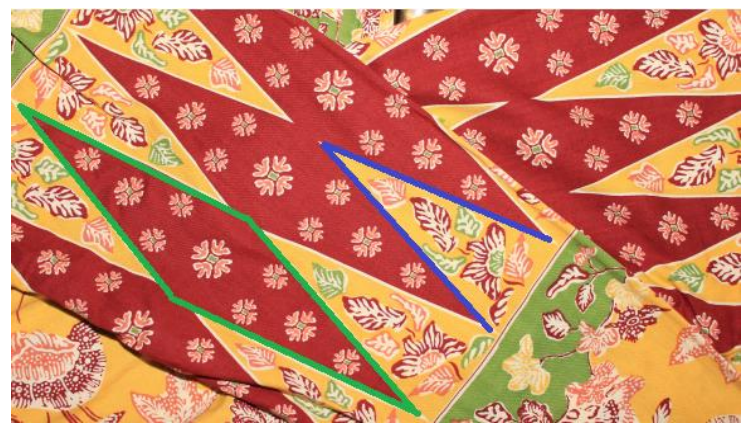

Source: https://belajarcerita.com/2017/12/12/batik-betawi-jakarta/

Picture 3. Batik Betawi Tumpal Pattern in 3D Image

Secondly, batik Betawi tumpal can be used as a learning medium for plane geometry lessons. This show in figure 3 that batik Betawi tumpal pattern can be used to learn about plane geometry. Learning medium is a tool, method and technique used to assist teachers and students in the teaching-learning process at school (Kurniawan, 2017). Mathematics is considered complicated and many students have difficulties in studying the subject due to the formulas that need to be memorised. One of the complicated materials is plane geometry, in 
which students have to distinguish and imagine the real shape other than those they find at school. Junior high school students are not familiar with self-learning methods and need guidance to develop their creative thinking. Besides, it is expected that using batik Betawi tumpal as a learning medium will help the students to understand the lesson easily. Therefore, providing them a learning medium is necessary.

Based on the mathematical literacy, it can be seen that several students had difficulties and could not comprehend plane geometry. It is obvious that some students had different literacy, ranging from high to lower mathematical literacy ability. Figures 4 and 5 show the examples of the variation in problem 7.
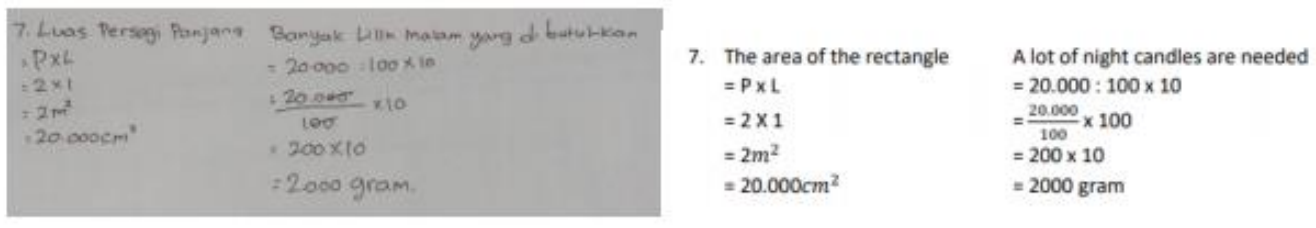

Figure 4. Answer from a Student with High Mathematical Literacy

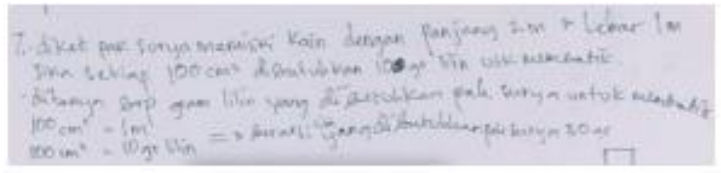

It is known thut Mr. Surya has a cloth weth a length of $2 \mathrm{~m}$ and a wisth of $1 \mathrm{~m}$. If every $100 \mathrm{~cm}{ }^{3}$ it takes 10 gr of wax to make batik. How many gams of wax does Mr. Surya need to make back. $100 \mathrm{~cm}^{2}=1 \mathrm{~m}$

$100 \mathrm{~cm}^{2}=10 \mathrm{gr}$ candie, it mears Mr. Surva nevds $30 \mathrm{gr}$ of the candie

Figure 5. Answer from a Student with Lower Mathematical Literacy

Mathematical literacy covers the ability to think creatively and critically in formulating, describing and elaborating a concept in line with mathematical concepts through the activity of reading and writing in everyday life. The ability to think critically is an act of thinking reasonable and rational before making a decision based on what is believed and what has been done (Kurniasih, 2017). Therefore, in this research, the researcher expected the students to make a decision when answering the problems. To improve the students' literacy, reading ability and reading habits are necessary. According to (Effendi, 2016), a person's ability in reading is fundamental in improving their thinking and reasoning ability which leads to expressing their opinion through words. If the students have been familiar with reading activity since their early age, they will have a high reasoning and thinking ability which in turn will affect their mathematical literacy.

Figure 4 is one of the sample answers of the student answered who had the highest grades. The answer of the students with high mathematical literacy will answer the problem according to the guidance, using the formula the formula taught by their teacher at school. 
Whereas in figure 5 is one of the sample answers of the student answered who had the lower grades. Students with lower mathematical literacy will give an appropriate answer. Figure 6 presents the students' mathematical literacy related to batik Betawi tumpal.

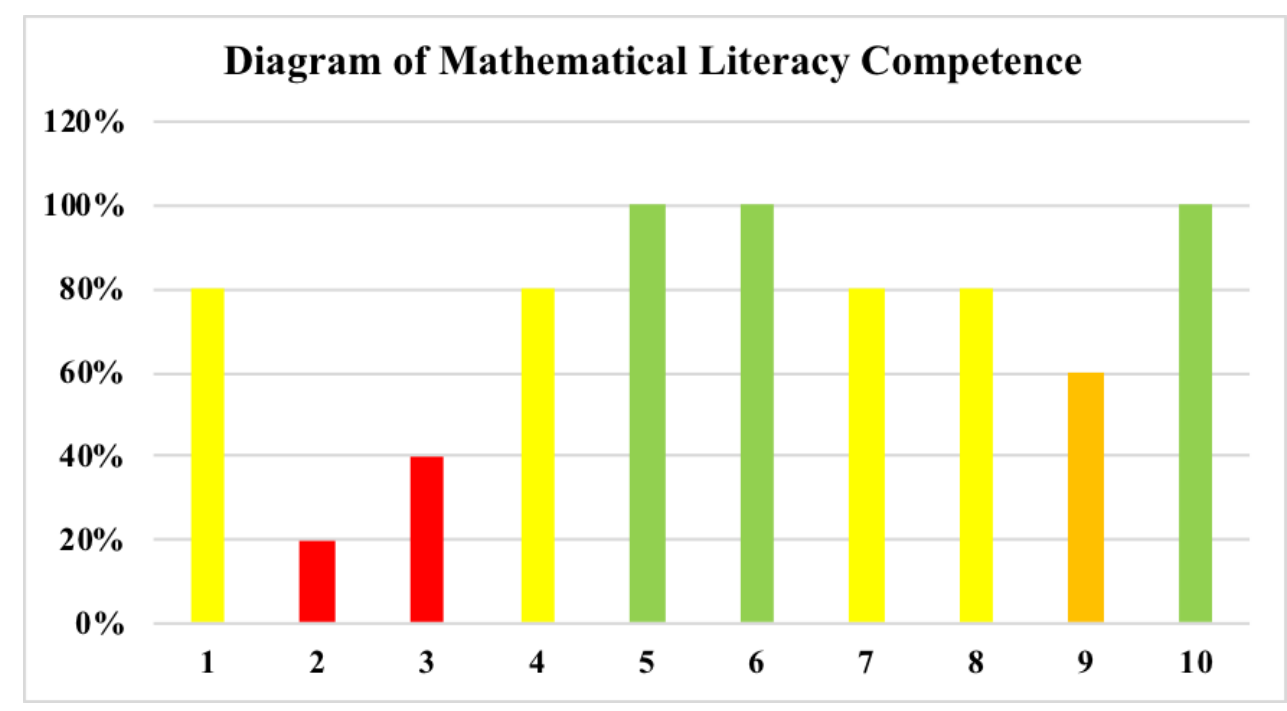

Figure 6. Diagram of Students Mathematical Literacy Competence

Batik Betawi tumpal is suitable as a learning medium for plane geometry lessons due to the following aspects. Cultural aspect of batik Betawi tumpal refers to the basic concept of mathematics that is plane geometry, such as triangles and rhombus. This cultural aspect refers to the basic competency 3.14: to analyse several quadrilaterals (square, rectangle, rhombus, parallelogram, trapezium and kite) and triangle according to their sides, angles and the correlation between angles and between sides, the basic competency 3.15: deriving the formula to find out the perimeter and the area of quadrilaterals (square, rectangle, rhombus, parallelogram, trapezium and kite) and triangles, the basic competency 4.14: solving the problems related to quadrilaterals (square, rectangle, rhombus, parallelogram, trapezium and kite) and triangles, and the basic competency 4.15: solving the contextual problems related to the area and the perimeter of quadrilaterals (square, rectangle, rhombus, parallelogram, trapezium and kite) and triangles. The learning activities using batik Betawi tumpal also refers to mathematical literacy indicators that are to identify the problems and transform them into mathematical questions and sort and apply the strategy of the simple problem solving based on different facts or resources.

Figure 6 shows the aspects of the tumpal pattern as a medium for plane geometry learning and students' ability based on the test consisting of ten problems. For problem 1, 
about the nature of the triangle sides, only $80 \%$ of students answered correctly. For problem 2 , regarding the nature of the triangle angles, only $20 \%$ answered correctly, showing that students did not understand the angle of the triangle. As for problem 3, only $40 \%$ of students answered correctly. For problem 4, about $80 \%$ of students answered correctly the perimeter of rectangular combination. Meanwhile, $100 \%$ of students answered problem 5 and 6 correctly. Based on these results, it can be concluded that students still have difficulty understanding the concept of plane geometry, while in general the students understand and can operate the formula well. With the use of batik Betawi tumpal pattern such as figure 7 it is expected that the students understand the concept of plane geometry.

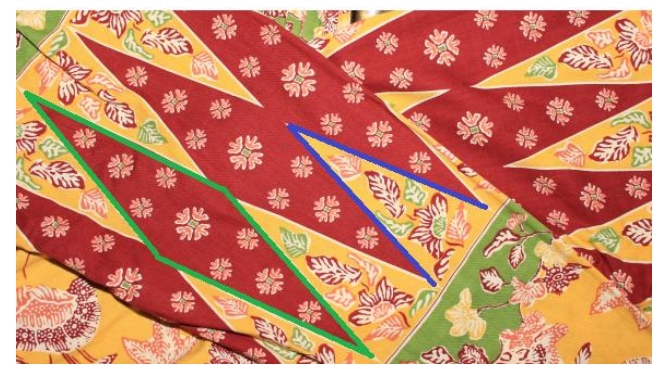

Source: https://belajarcerita.com/2017/12/12/batik-betawi-jakarta/

Figure 7. Batik Betawi Tumpal with Plane Geometry Concept (Triangle and Rhombus)

The research was related to research by (Rakhmawati, 2016) with the title "Cultural-Based Mathematical Activities in the Lampung Community." The results of the re search study stated that there are special ways in Lampung people in carrying out mathematical activities. There is a similarity in research, namely examining related matters of culture and mathematics or commonly known as ethnomatematics. Meanwhile this research about batik Betawi tumpal pattern can be used as a learning medium for plane geometry.

The following is a sample of the students' worksheet of batik Betawi tu mpal developed and used in this study.

WORKSHEET PLANE GEOMETRY BASED ON BATIK BETAWI TUMPAL
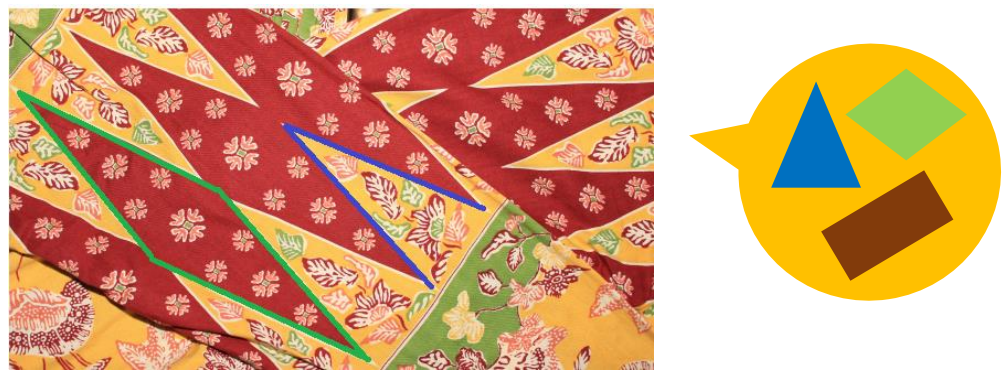

Source: https://belajarcerita.com/2017/12/12/batik-betawi-jakarta/ 


\section{Standard of Competency:}

3. Understanding the characteristic and element, and being able to solve problems related to plane geometry (triangles and quadrilaterals) based on Betawi Culture.

\section{Basic of Competency:}

3.14 Analysing different quadrilaterals (square, rectangle, rhombus, parallelogram, trapezium and kite) and triangles based on sides, angles and relation between sides and between angles based on Betawi culture.

3.15 Deriving the formulas to find out the perimeter and area of quadrilaterals (square, rectangle, rhombus, parallelogram, trapezium and kite) and triangles based on Betawi culture.

4.14 Solving problems related to quadrilaterals (square, rectangle, rhombus, parallelogram, trapezium and kite) and triangles based on Betawi culture.

4.15 Solving the contextual problems related to the perimeter and area of rectangles (square, rectangle, rhombus, parallelogram, trapezium and kite) and triangles based on Betawi culture.

\section{Attainment Indicator:}

1. Identifying a plane geometry of quadrilaterals (square, rectangle, rhombus, parallelogram, trapezium and kite) and triangles based on sides, angles and relation between sides and between angles based on Betawi culture.

2. Solving problems related to the area and circumference of quadrilaterals (square, rectangle, rhombus, parallelogram, trapezium and kite) and triangles based on sides, angles and relation between sides and between angles based on Betawi culture.

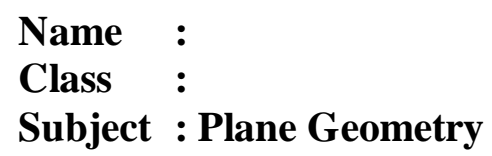

\section{Instructions:}

1. Pray before doing your work.

2. A smartphone, calculator, laptop are not allowed. No discussion with other students.

3. Read the problems carefully.

4. Make a drawing for every problem.

5. Write the steps of solving and elaborate the reason to your answer clearly, completely and orderly in the answer sheet.

\section{Task}

1. Look at the following figure! 


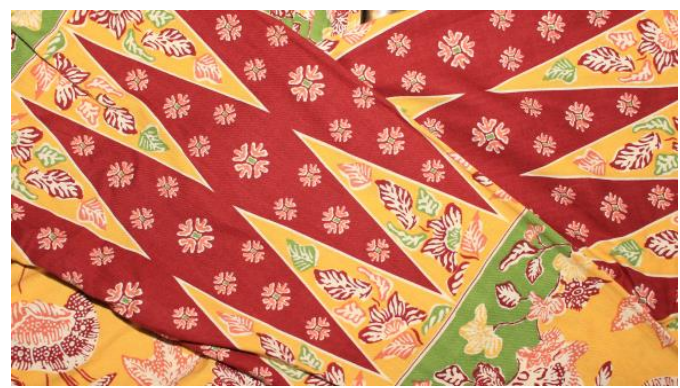

Batik Betawi has a pattern like plane geometry and one of them is a triangle. If $\mathrm{ABC}$ Triangle has side of $A B=B C$. What type of a triangle is it? Explain using the characteristics of a triangle!

2. For triangle $\mathrm{PQR}$, it is known that $P=60^{\circ}$ and $Q=80^{\circ}$. What type of triangle is PQR? Explain using the characteristics of a triangle!

3. A sheet of batik Betawi fabric is a quadrilateral.

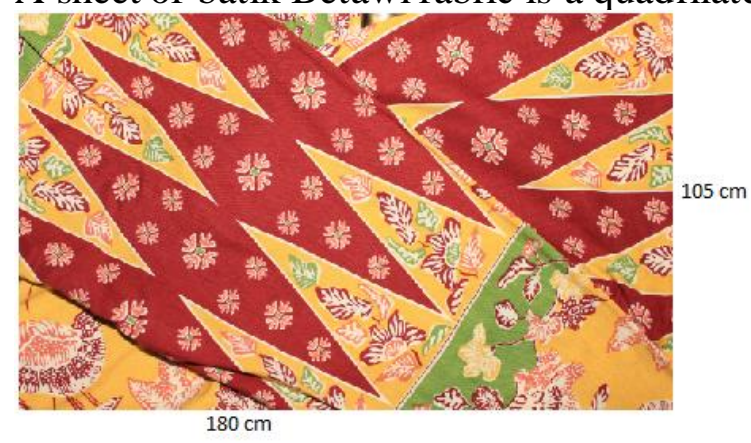

Is the sheet of fabric a rectangle if the diagonal length is $90 \mathrm{~cm}$ ? Prove your answer!

4. If two rectangles are overlapping and forms a L letter shape, as shown in the Figure below. Find the perimeter of the shape!

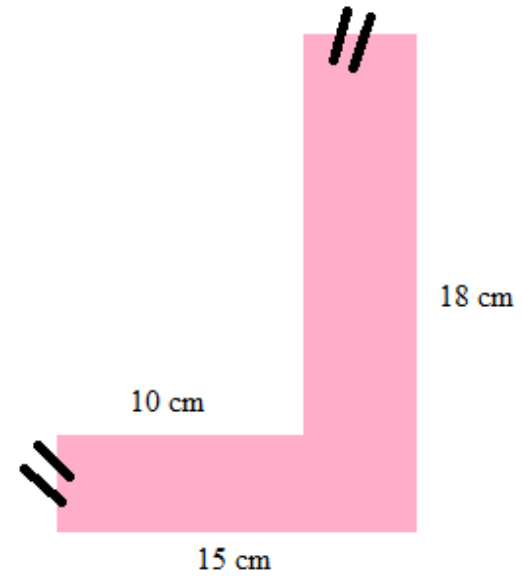


5. Look at the figure below!

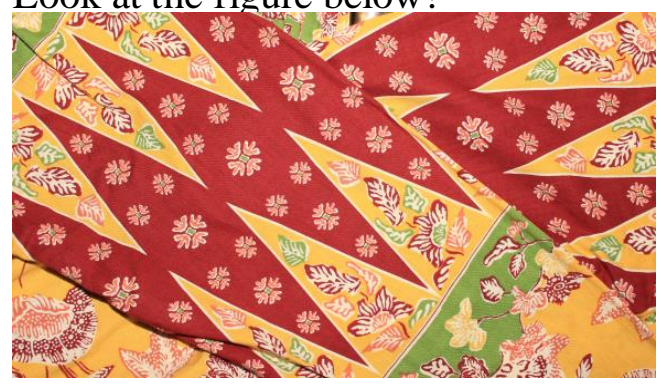

The ratio between the length and width of a sheet batik Betawi is 7:4. If the perimeter of the sheet is $66 \mathrm{~cm}$. Find the area!

6. Look at the following figure!

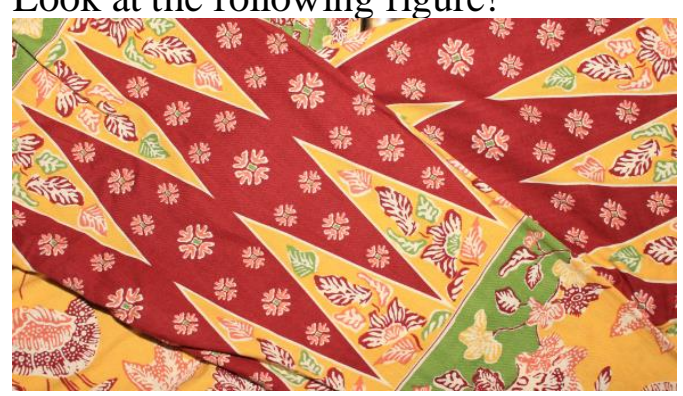

In a sheet of batik Betawi, there are rhombuses, with the diagonal length of $24 \mathrm{~cm}$. If the area of the rhombus is $120 \mathrm{~cm}$, what is the perimeter of the rhombus?

7. Mr. Surya wants to draw a batik pattern in a cotton sheet with a length of $2 \mathrm{~m}$ and width of $1 \mathrm{~m}$. If he need $10 \mathrm{gram}$ of wax for every $100 \mathrm{~cm}^{2}$, how many grams of wax does he need to do the work?

8. Look at the following figure!

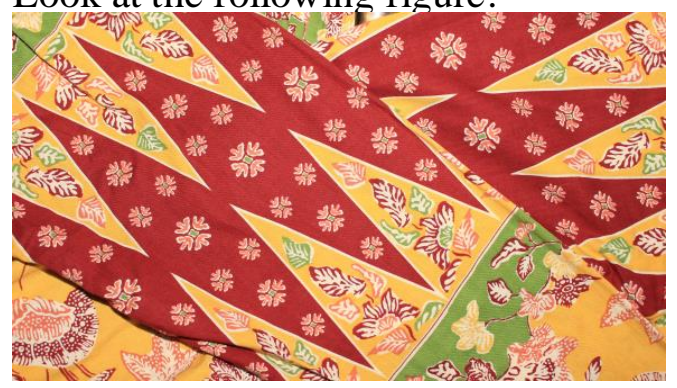

In the sheet of batik Betawi, there are quadrilaterals. Are the two diagonals perpendicular to each other? Why?

9. In a sheet of batik Betawi fabric, there are some rhombuses. Every edge of the rhombus is decorated with golden ink, which cost $R p .47 .000,00$. for $5 \mathrm{~m}$. If there is a rhombus with the length of $60 \mathrm{~m}$, how much is the cost to decorate the edge of rhombus in a sheet of batik fabric?

10. The height of a parallelogram is twice of its base length. If the area of the parallelogram is $162 \mathrm{~cm}^{2}$. Find the base and the height! 


\section{CONCLUSION}

Based on the data analysis and results, it can be concluded that batik Betawi has several types of patterns. One of the patterns that can be used as a learning medium for mathematics lessons at school is batik Betawi tumpal. It has a plane geometry pattern in it. Batik Betawi has triangles and varied shapes of quadrilaterals. This will help the students in learning. Furthermore, it will be more beneficial if the learning involves other Indonesian cultural elements which never exposed before.

Students looked very excited when introduced to a learning medium of batik Betawi tumpal and most of them had never known that batik has patterns like plane geometry. Most of them were only familiar with ondel-ondel since only ondel-ondel patterns are easily found in the market. This pattern was found several centuries ago while batik Betawi tumpal was invented in the twentieth century. Students' mathematical literacy might be improved significantly because the students study excitedly as they are exposed to the new learning medium, such as batik Betawi tumpal. Batik Betawi a learning medium can also introduce Betawi culture to students to preserve one of the elements of Betawi cultural wealth. It is also hoped that this research can be one of the reference materials to help further researchers to explore Indonesian cultures related to mathematics.

\section{REFERENCES}

Abi, A. (2017). Integrasi Etnomatematika Dalam Kurikulum Matematika Sekolah. JPMI (Jurnal Pendidikan Matematika Indonesia), $\quad 1(1), \quad 1$. https://doi.org/10.26737/jpmi.v1i1.75

Afriyanti, I., Wardono, \& Kartono. (2018). Pengembangan Literasi Matematika Mengacu PISA Melalui Pembelajaran Abad Ke-21 Berbasis Teknologi. PRISMA, Prosiding Seminar Nasional Matematika, 1, 608-617.

Alghadari, F. (2017). Tradisi Nirok-Nanggok Masyarakat Belitung: Sejarah Dan Kaidah Matematis. KALAMATIKA Jurnal Pendidikan Matematika, 2(1), 39. https://doi.org/10.22236/kalamatika.vol2no1.2017pp39-50

Budaya, M. N., Sastra, D., Jurusan, O. A., Uin, M., Malik, M., \& Malang, I. (2017). *) Disampaikan dalam Seminar Nasional Matematika dan Pendidikannya "Kontribusi 
KALAMATIKA, Volume 6, No. 1, April 2021, pages 83-98

Matematika dalam Strategi Internalisasi Nilai Budaya dalam Pembelajaran Matematika.

Effendi, R. (2016). Model Pembelajaran Sq3R Untuk Mengembangkan Kemampuan Literasi Siswa. KALAMATIKA Jurnal Pendidikan Matematika, 1(2), 109. https://doi.org/10.22236/kalamatika.vol1no2.2016pp109-118

Fathani, A. H. (2016). Pengembangan Literasi Matematika Sekolah Dalam Perspektif Multiple Intelligences. Jurnal EduSains, 4(2), 136-150.

Hera, R., \& Sari, N. (2015). Seminar Nasional Matematika Dan Pendidikan Matematika UNY 2015713 Literasi Matematika: Apa, Mengapa dan Bagaimana? 713-720.

Khotimah. (2018). Meningkatkan Kemampuan Literasi Matematis Dengan Pendekatan Metacognitive Guidance ( Improving Mathematical Literacy Skills Using. 01(01), 5365.

Kurniasih, M. D. (2017). Pengaruh Pembelajaran React Terhadap Kemampuan Berpikir Kritis Matematis Ditinjau Dari Habit of Mind Mahasiswa. KALAMATIKA Jurnal Pendidikan Matematika, 2(1), 29. https://doi.org/10.22236/kalamatika.vol2no1.2017pp29-38

Kurniawan, D. T. (2017). Penggunaan Model Pjbl Untuk Meningkatkan Kreativitas Mahasiswa Dalam Membuat Media Pembelajaran Matematika. Kalamatika Jurnal $\begin{array}{lll}\text { Pendidikan } & \text { Matematika, } & 2(2),\end{array}$ https://doi.org/10.22236/kalamatika.vol2no2.2017pp207-220

Kusumowardhani, P. (2017). Identifikasi Unsur Visual Bentuk dan Warna yang Menjadi Ciri Khas Motif Ragam Hias Batik Betawi Tarogong Jakarta. Seminar Nasional Seni Dan Desain 2017, 97-105.

Lusiana, D., Afriani, N. H., Ardy, H., \& Widada, W. (2019). Eksplorasi Etnomatematika Pada Masjid Jamik Kota Bengkulu. Jurnal Pendidikan Matematika Raflesia, 04(02), 164176.

Maryati, I., \& Priatna, N. (2018). Analisis Kemampuan Literasi Statistis Siswa Madrasah 
Tsanawiyah dalam Materi Statistika. Journal of Medives: Journal of Mathematics $\begin{array}{lllll}\text { Education } & \text { IKIP } & \text { Veteran } & \text { Semarang, }\end{array}$ https://doi.org/10.31331/medives.v2i2.640

Rakhmawati. (2016). Aktivitas Matematika Berbasis Budaya pada Masyarakat Lampung. 7(2), 221-230.

Setiadi, E.M., Hakam, K.A., Effendi, R. (2017). Ilmu Sosial\&Budaya Dasar. Jakarta: PT Fajar Interpratama Mandiri

Soedarwanto, H., Muthi'ah, W., \& Maftukha, N. (2018). Kajian Ekspresi Seni Dalam Ragam Hias Batik Betawi. NARADA, Jurnal Desain \& Seni, 5(1), 67-79.

Stacey, K. (2015). Selected Regular Lectures from the 12th International Congress on Mathematical Education. Selected Regular Lectures from the 12th International Congress on Mathematical Education, 771-790. https://doi.org/10.1007/978-3-319$17187-6$

Sugiyono. (2016). Metode Penelitian Kuantitatif, Kualitatif, Dan R\&D. (23rd Ed.). Alfabeta.

Supriadi, Arisetyawan, A., \& Tiurlina. (2016). Mengintegrasikan Pembelajaran Matematika Berbasis Budaya Banten Pada Pendirian Sd Laboratorium Upi Kampus Serang. Mimbar Sekolah Dasar, 3(1), 1-18. https://doi.org/10.17509/mimbar-sd.v3i1.2510

Yenni, Y. (2016). Pengaruh Model Pembelajaran Learning Cycle Terhadap Kemampuan Pemahaman Dan Koneksi Matematis Siswa Smp. KALAMATIKA Jurnal Pendidikan Matematika, 1(1), 71. https://doi.org/10.22236/kalamatika.vol1no1.2016pp71-83

https://belajarcerita.com/2017/12/12/batik-betawi-jakartal. Accessed on 08/02/2020 
98 KALAMATIKA, Volume 6, No. 1, April 2021, pages 83-98 